\title{
Institutional barriers to a 'perfect' policy: a case study of the Senegalese Rural Electrification Plan
}

\author{
Rebecca Mawhood*, Robert Gross \\ Imperial College Centre for Energy Policy and Technology, Imperial College London \\ * Correspondence to: \\ Centre for Environmental Policy, Imperial College London, London SW7 1NA \\ rebecca.mawhood11@imperial.ac.uk
}

Energy Policy, October 2014, Volume 73, pp. 480-490

DOI: 10.1016/j.enpol.2014.05.047

\begin{abstract}
:
This paper investigates the political and institutional factors that have influenced the success of the Senegalese Rural Electrification Action Plan (Plan d'Action Sénégalais d'Électrification Rurale, PASER). PASER is of interest because its innovative design attracted extensive offers of finance from donors and independent power providers, however it has had limited effect on electrification levels. This paper examines PASER's progress and problems in detail, with the aim of informing rural electrification policy internationally.
\end{abstract}

An extensive literature review was combined with 26 semi-structured stakeholder interviews, to produce a snapshot of the Plan's status after its first decade of operation. PASER's experiences are compared with other reform-based rural electrification initiatives across Sub-Saharan Africa.

PASER has faced significant institutional and political barriers, with delays arising from organisational opposition, inconsistent ministerial support, protracted consultations and the inherent challenges of implementing an innovative policy framework in a country with limited institutional capacity. The development of human and institutional capacity has been compromised by inconsistent political commitment. Such experiences mirror those of electrification initiatives across Sub-Saharan Africa. Whilst PASER's successes in garnering external support and fundraising are noteworthy and won praise from early reviews, in terms of delivery the Plan has failed to resolve common institutional barriers.

\section{Keywords:}

Rural electrification; institutional barriers; power sector reform

\section{Highlights}

- Factors influencing the Senegalese Rural Electrification Action Plan are investigated.

- 26 stakeholder interviews inform a review of the Plan after 10 years of operation.

- The Plan has attracted extensive finance, but installations are severely delayed.

- The delays are found to be largely the result of institutional and political barriers.

- These barriers mirror the experiences of electrification initiatives across Africa. 


\section{Introduction}

Sub-Saharan Africa (SSA) ${ }^{1}$ has some of the lowest levels of energy access and human development in the world (UNDP, 2012; IEA, 2011), with inadequate electricity services considered a primary barrier to socioeconomic development in the region (Onyeji, Bazilian \& Nussbaumer, 2012; Gelb et al., 2007). Expenditure on electricity is insufficient to maintain reliable services within the existing infrastructure, let alone extend provision to the whole population (AfDB, 2010). Spending across the region's entire power sector was $\$ 11.6$ billion $^{2}$ in 2010 (Foster \& Briceño-Garmendia, 2010). Estimates from the IEA and the African Development Bank suggest that additional investment of the order of $\$ 20$ billion per year is needed to meet existing and future needs, and to realise universal access by 2030 (IEA, 2011; AfDB, 2010).

Public funds currently account for $78 \%$ of global investments in energy access and $89 \%$ of investments in the Sub-Saharan African electricity sector (IEA, 2011; Foster \& Briceño-Garmendia, 2010). However many analysts stress the importance of increasing private investment in energy for developing countries. The IEA (2011) suggests that the proportion of private investment needs to increase from $22 \%$ to $31 \%$ to achieve universal energy access. Moreover, many of the poorest countries rely heavily for power sector investment on finance and support from the World Bank and the IMF. Since the 1990s these organisations have often conditioned their financial support on structural changes and/or privatisation (Massé, 2010; Wamukonya, 2003). As part of such reforms many countries have created a Rural Electrification Agency and/or Fund (ibid.). These are semiautonomous organisations responsible for managing multi-year funds across projects implemented by numerous actors (Mostert, 2008). The creation of these new institutions, independent from incumbent electricity companies and partially independent of governments, represents a significant departure from the historically dominant model in the region: most rural electrification initiatives have instead been implemented by the national electricity company, usually a vertically integrated state monopoly. It is important to note that the conventional model of incumbent-led, largely statesubsidised rural electrification programmes has continued to be applied in several countries with considerable success (Boubou, Watchueng \& Massé, 2010; Massé, 2010).

This paper investigates in detail experience to date with one approach devised to enhance private sector investment and engagement in electrification in SSA: the Senegalese Rural Electrification Action Plan (Plan d'Action Sénégalais d'Électrification Rurale, PASER). PASER was established in 2002 as a result of electricity sector reforms (Massé, 2010; Sow, 2006). Early reviews of PASER considered it an exciting, innovative and well-supported scheme, which had succeeded in attracting unusually high levels of private sector finance and therefore offered a hopeful model for rural electrification (hereafter referred to as RE) elsewhere. More recent updates note that PASER's implementation has been slow but do not explain the causes of the delay (AFD, 2012; World Bank, 2012a; DECRS, 2009; Gihr, 2009). This paper provides a thoroughgoing review of PASER's progress and explores the causes of delays and difficulties experienced, with the aim of informing the development of RE policy internationally.

\footnotetext{
${ }^{1}$ This article uses the following non-standard abbreviations: ASER, Senegalese Rural Electrification Agency; PASER, Senegalese Rural Electrification Action Plan; RE, rural electrification; SSA, Sub-Saharan Africa.

2 s refers to USD throughout. The following conversion rates have been applied to sums referenced in other currencies: 1 CFA franc $=\$ 0.00199955 ; € 1=\$ 1.31024(X E, 2012)$.
} 
The rest of the paper proceeds as follows: section 2 describes the methodology; section 3 details the results of the literature review, providing background on the Senegalese electricity sector, the historical development of PASER, the aims and structure of the Plan, and the first decade of PASER's operation; section 4 provides the results of the stakeholder interviews regarding the nature and impacts of barriers to PASER; section 5 compares the experiences of PASER with other RE initiatives in SSA; section 6 provides conclusions and policy recommendations.

\section{Methods}

The study presents the findings of an extensive critical review of published and unpublished literature combined with 26 semi-structured interviews with key stakeholders in PASER. The following provides further details of the methods employed.

\subsection{Critical literature review}

The critical review was conducted in three phases:

- A narrative review of academic and grey literature provided contextual information on rural electrification in Sub-Saharan Africa and the specific situation of Senegal.

- A survey of published documentation about PASER established the existing lack of consensus about the Plan's success or otherwise. Sources were selected based on the following inclusion criteria: explicit coverage of PASER's achievements; explicit assessment or opinion of PASER's progress and/or effectiveness; availability through Imperial College's library catalogue or the internet.

- An investigative review of Senegalese grey literature provided the basis for the review of PASER's design and achievements and helped to identify issues for exploration in interviews as well as potential interviewees. Much of the literature is not available in the public domain but was gathered directly from stakeholders.

\subsection{Semi-structured interviews}

Semi-structured interviews were the primary data collection method used to investigate PASER's progress and the causes of its delays. The interviews were used to verify factual data about PASER's design and achievements, and to gather qualitative information about interviewees' experiences. In particular interviewees were questioned about their views of: PASER (as a concept and in practice); the extent and rate of installations realised; the difficulties and successes experienced by the Plan, and the causes thereof. The semi-structured interview method is well-suited to these aims because it allows the exploration of matters resistant to direction observation, the reconstruction of events, and broad coverage of individuals and situations. Further the method's inherent flexibility allows questions to be tailored to interviewees' responses, enabling iterative collection and analysis of data during the interview (Bryman, 2008).

\subsubsection{Interview technique}

Twenty-six key stakeholders of PASER were interviewed, of whom twenty were selected by purposive sampling and six by snowball sampling. The interviewees include representatives of the following stakeholder groups, referenced throughout this paper with bracketed keywords: international and national government agencies (Government); donor organisations (Donor); 
independent power providers and installation coordinators (Business); independent consultants and researchers (Consultant); and beneficiaries. To minimise bias a minimum of two representatives were interviewed from each stakeholder group, responses of interviewees were triangulated with each other and with the literature, and the interviewees were provided anonymity.

Questions were tailored according to the interviewees' involvement in PASER and the organisation they represented. Interviews with representatives of the different stakeholder groups were conducted in a purposefully jumbled order, allowing different perceptions of key issues to be captured in early interviews for exploration with representatives of the other stakeholder groups in subsequent interviews. This aspect was very important due to the lack of publically-available information about PASER (the premise of the study), which impeded the identification of key issues in the early stages of research.

All the interviews were conducted face-to-face. Twenty-one were held in French and two in English. Three interviews were conducted in languages of African origin with the aid of an interpreter.

\subsection{Data analysis}

Data were analysed qualitatively using the three-step process described by Jupp (2006): rationalisation of data; presentation of data to be relevant to the research objectives; identification of key themes and patterns from which to draw conclusions. This was supplemented with root cause analysis to identify the underlying causes of delays. Root cause analysis is usually conducted in three phases: target problems detection; root cause detection; corrective action innovation (Lehtinen, Mäntylä \& Vanhanen, 2011). Since the study did not aim to resolve problems experienced, the final phase was substituted with the formulation of policy implications.

\section{Literature review - Back ground on the Senegalese approach to rural electrification}

\subsection{An introduction to Senegal}

Located in the West African Sahel, the Republic of Senegal has an area of $197,712 \mathrm{~km}^{2}$ and an estimated population of 12.9 million (ANSD, 2012). It is considered a model democracy in Africa (BBC, 2012). Purchasing power parity GDP was $\$ 25.1$ billion in 2010 ( $\$ 1,850$ per capita) (World Bank, 2012b) and the country's economic prospects appear to be improving: in 2011 the IMF reclassified Senegal from a low-income, non-fragile country to a middle-income country (IMF, 2011). Nonetheless, $46.7 \%$ of Senegal's national population, and $57.3 \%$ of its rural population, were considered to be living in poverty in 2011 (IMF, 2012).

Senegal's electricity sector is heavily dependent on thermal generation fuelled largely by imported oil (Enerdata, 2011). It has good renewable energy resources although these are little utilised, with the exception of large-scale hydro (IRENA, 2012; ECJRC, 2011; Enerdata, 2011). The national electricity company, Senelec, held a public monopoly over electricity production, transmission and distribution until 1998, and continues to account for $70 \%$ of electricity production (Enerdata, 2011). Senelec has been heavily dependent on subsidies for decades (Sanoh et al., 2012). It struggles to maintain and invest in new plant and, at times, to pay its suppliers (Sanoh et al., 2012; Fritsch, 2011; Eberhard et al., 2008). Senegal suffers from frequent, prolonged blackouts (Fofana, 2011; Dabo, 
2006; Dioh, 2003). The national electrification level $\left.\right|^{3}$ stands at $54 \%$, masking a large disparity between urban (90\%) and rural (24\%) areas (Niang, 2011). The investment needed to increase the RE level to 50\% was estimated at \$476 million in 2009 (Sow, 2009).

\subsection{The 1998 electricity sector reforms and the Senegalese Rural Electrification Action Plan (PASER)}

Until 1998 RE was managed through small-scale covenants between the government and Senelec. These were implemented without a long-term strategy (Niang, 2006; Sow, 2004). Efforts focussed on medium-voltage grid expansion with a few villages electrified by decentralised generators (Ngom, 2009, Hoang-Gia, 1998). Production, transportation and distribution infrastructure were largely state-funded, but connection fees and internal installation costs were passed directly to consumers (De Gouvello \& Kumar, 2007). By the late 1990s it was understood that this model was ineffective on several counts (Niang, 2011): the RE level was just 5\% in 1997 (and at risk of falling) (Hoang-Gia, 1998); neither Senelec nor potential customers had sufficient resource to cover the high upfront investment costs (De Gouvello \& Kumar, 2007); the selection of villages was viewed as inequitable, being based on proximity to the existing grid or political motivations (Government 3, 2012); and scepticism about renewable and decentralised solutions had prevented their deployment .

Major electricity sector reforms were undertaken in 1998. At the time the World Bank had ceased lending to the Senelec (Gökgür \& Jones, 2006), but it and the IMF agreed to provide further concessionary loans if privatisation-focussed reforms were implemented (Fall \& Wamukonya, 2003). Senelec was partially privatised in 1999 but renationalised in 2000. A second attempt to privatise Senelec in 2001 also failed (Gökgür \& Jones, 2006). However important reforms did take place regulation and RE responsibilities were removed from Senelec's portfolio and assigned to two new institutions: the Electricity Sector Regulatory Commission (Commission de Régulation du Secteur de I'Électricité) and the Senegalese Rural Electrification Agency (Agence Sénégalaise d'Électrification Rurale, ASER) (Niang, 2006). ASER was given sole responsibility for promoting RE (GoS, 1999). The Agency's responsibilities include: development of RE programmes; provision of financial and technical assistance; coordination of tenders and proposals from private operators for electricity service concessions; and supervision of contracted installations (Niang, 2006; GoS, 1998; Hoang-Gia, 1998). It administers the Senegalese Rural Electrification Action Plan (Plan d'Action Sénégalais d'Électrification Rurale, PASER). This innovative 20-year strategy was designed to mobilise private sector investment in $\mathrm{RE}$, and developed with financial and technical support from the World Bank (ESMAP, 2007). An early outline of the Plan proposed two principal objectives: to make electrification services available in $80 \%$ of rural communities by 2015 ; and to increase the national RE level from the 1997 baseline of $5 \%$ to $8 \%$ by 2005, 30\% by 2015 and $60 \%$ by $2022^{4}$ (Hoang-Gia, 1998).

\footnotetext{
${ }^{3}$ National/rural electrification level refers to the percentage of national/rural households that have an electricity service (grid-connected or individual generator/renewable energy system).

${ }^{4}$ These targets have been revised on multiple occasions, resulting in considerable confusion as to the level of official current targets amongst stakeholders (Mawhood, 2012). Variations on PASER's original targets were the most commonly cited by interviewees and so are the analytical point of comparison for this paper.
} 
PASER is split into three complementary programmes:

- the Rural Electrification Priority Programme (Programme Prioritaire de l'Électrification Rurale), which coordinates regional-scale concessions for electricity services;

- the Local Initiative for Rural Electrification (Électrification Rurale d'Initiative Locale), which promotes small-scale concessions for communities not benefitting from the priority programme;

- the Multi-sector Energy Programme (Programme Énergétique Multisectoriel), which aims to broaden the social and economic benefits of electrification.

The Rural Electrification Priority Programme is PASER's principal mechanism for increasing RE levels and the most advanced of the Plan's three programmes. It is projected to result in over 163,000 new household connections by 2017 (ASER, 2012d). Under the Priority Programme Senegal's rural regions are divided into ten geographical concessions (ASER \& DESI, 2012). Contracts to provide electricity services in each concession, for twenty-five years, are awarded by technology-neutral competitive tender. The winning bid is that which proposes to connect the greatest number of households in return for a predefined output-based subsidy (an additional subsidy is available for renewable technologies). This tender design encourages independent power providers to seek supplementary funding to increase their bid, thus increasing private investment in the sector (De Gouvello \& Kumar, 2007; ESMAP, 2007).

Alongside PASER several more conventional RE initiatives have been implemented since the 1998 reforms:

- The historical model of state-funded covenants has continued, with covenants coordinated by either ASER or Senelec (Government 5, 2012).

- One of ASER's major programmes over 2008-2012 was the Emergency Programme (Programme $d^{\prime}$ Urgence). This was similar in design to the covenants, albeit with more accessible payment terms for consumers (Diop, 2009). A second Emergency Programme has been proposed for 2014-2016 (GoS, 2013).

- Various individual projects have been implemented by non-governmental organisations and private companies, financed predominantly by international development funds (Sylla, 2011).

\subsection{PASER's progress: 2002-2012}

\subsubsection{Donor commitments and private sector bids}

PASER has attracted offers of finance from donors in excess of $\$ 159$ million (ASER, 2012c). Both the extent of funds offered and the number of development organisations keen to participate are considered unusual for RE (Donor 1, 2012).

Leading international independent power providers (IPPs) have also promised considerable support. The first six Priority Programme concessions were awarded to Office National de l'Électricité (ONE) and Société Tunisienne de l'Électricité et du Gaz (STEG) (respectively the Moroccan and Tunisian national electricity companies), EDF and Isofoton, with four contracts in partnership with Senegalese firms (Table 1). The winning bids secured a total of $\$ 52$ million of private finance, representing an average $49 \%$ of the total investment (ibid.). This is significantly greater than the minimum $20 \%$ required by the invitations to tender and well above the global average of $22 \%$ for energy access investments (IEA, 2011). The number of connections proposed by IPPs was also twice that required 
by the invitations to tender on average (Table 1). These figures suggest that the Priority Programme's design aims - to leverage private finance and to maximise the number of new connections - are being realised.

Table 1 Summary of tender results for the first six Priority Programme concessions at August 2012. Source data: (Sarr, Personal communication-a; Sarr, Personal communication-b; ASER, 2012a; ASER, 2012d; ASER \& DESI, 2012; Niang, 2011).

\begin{tabular}{|c|c|c|c|c|c|c|c|}
\hline Concession & $\begin{array}{l}\text { 1. Dagana- } \\
\text { Podor-Saint } \\
\text { Louis }\end{array}$ & $\begin{array}{l}\text { 2. Louga- } \\
\text { Kébemer- } \\
\text { Linguère }\end{array}$ & $\begin{array}{l}\text { 3. Kaffrine- } \\
\text { Tamba- } \\
\text { Kedougou }\end{array}$ & 4. Mbour & $\begin{array}{c}\text { 5. Fatick- } \\
\text { Gossas- } \\
\text { Kaolack- } \\
\text { Nioro }\end{array}$ & $\begin{array}{l}\text { 6. Kolda- } \\
\text { Vélingara }\end{array}$ & Total \\
\hline $\begin{array}{l}\text { Development } \\
\text { funder }\end{array}$ & World Bank & $\begin{array}{c}\text { African } \\
\text { Development } \\
\text { Bank }\end{array}$ & $\begin{array}{c}\text { Agence } \\
\text { Française de } \\
\text { Développement }\end{array}$ & World Bank & KfW & EU & \\
\hline IPP & $\begin{array}{c}\text { ONE } \\
\text { Compagnie } \\
\text { Marocain- } \\
\text { Sénégalaise } \\
\text { d'Electricité } \\
\text { (ONE } \\
\text { COMASEL) }\end{array}$ & ONE & $\begin{array}{l}\text { EDF \& Matforce } \\
\text { Énergie Rurale } \\
\text { Africaine }\end{array}$ & $\begin{array}{c}\text { STEG \& } \\
\text { Consortium } \\
\text { Sénégalais } \\
\text { d'Électricité et } \\
\text { les Câbleries du } \\
\text { Sénégal } \\
\text { (COSELEC- LCS) } \\
\text { (provisional) }\end{array}$ & $\begin{array}{l}\text { Isofoton \& } \\
\text { ENCO) } \\
\text { (provisional) }\end{array}$ & $\begin{array}{l}\text { Isofoton \& } \\
\text { ENCO } \\
\text { (provisional) }\end{array}$ & \\
\hline \multicolumn{8}{|c|}{ Finance (\$ million) } \\
\hline $\begin{array}{l}\text { Total } \\
\text { investment }\end{array}$ & 18.5 & 18.4 & 15.8 & 14.9 & 22.8 & 15.9 & 106 \\
\hline $\begin{array}{l}\text { Subsidy value } \\
\text { (incl. govt. } \\
\text { contribution) }\end{array}$ & 6.4 & 14.3 & 10.1 & 5.4 & 6.8 & 11.0 & 54.0 \\
\hline $\begin{array}{l}\text { Private } \\
\text { finance }\end{array}$ & 12.1 & 4.1 & 5.7 & 9.4 & 16.0 & 4.9 & 52.3 \\
\hline $\begin{array}{l}\text { Private } \\
\text { finance (\%) }\end{array}$ & $65 \%$ & $22 \%$ & $36 \%$ & $63 \%$ & $70 \%$ & $31 \%$ & $49 \%$ \\
\hline \multicolumn{8}{|c|}{ Electrical connections } \\
\hline $\begin{array}{l}\text { Minimum } \\
\text { connections } \\
\text { required by } \\
\mathrm{ITT}^{\mathrm{a}}\end{array}$ & 8,500 & 8,500 & 13,000 & 7,500 & 8,500 & 7,000 & 53,000 \\
\hline $\begin{array}{l}\text { Connections } \\
\text { proposed by } \\
\text { IPP }^{\text {a }}\end{array}$ & 19,574 & 11,826 & 18,001 & 9,700 & 27,000 & 20,500 & 106,601 \\
\hline
\end{tabular}

a. Connections to be completed within the first $\mathbf{3 6}$ months of the concession.

\subsubsection{Rural electrification - the role of PASER}

Figure 1 compares Senegal's national RE levels over 1997 to $2011^{5}$ with national RE targets, which are formal objectives of PASER.

The level of RE has more than doubled since 2002 (when PASER was established), and has so far exceeded targeted rates. The trend-line for RE since PASER's inauguration suggests that the target of $60 \%$ by 2022 will be narrowly missed.

\footnotetext{
${ }^{5}$ Data for 2012 were not available at the time of writing.
} 


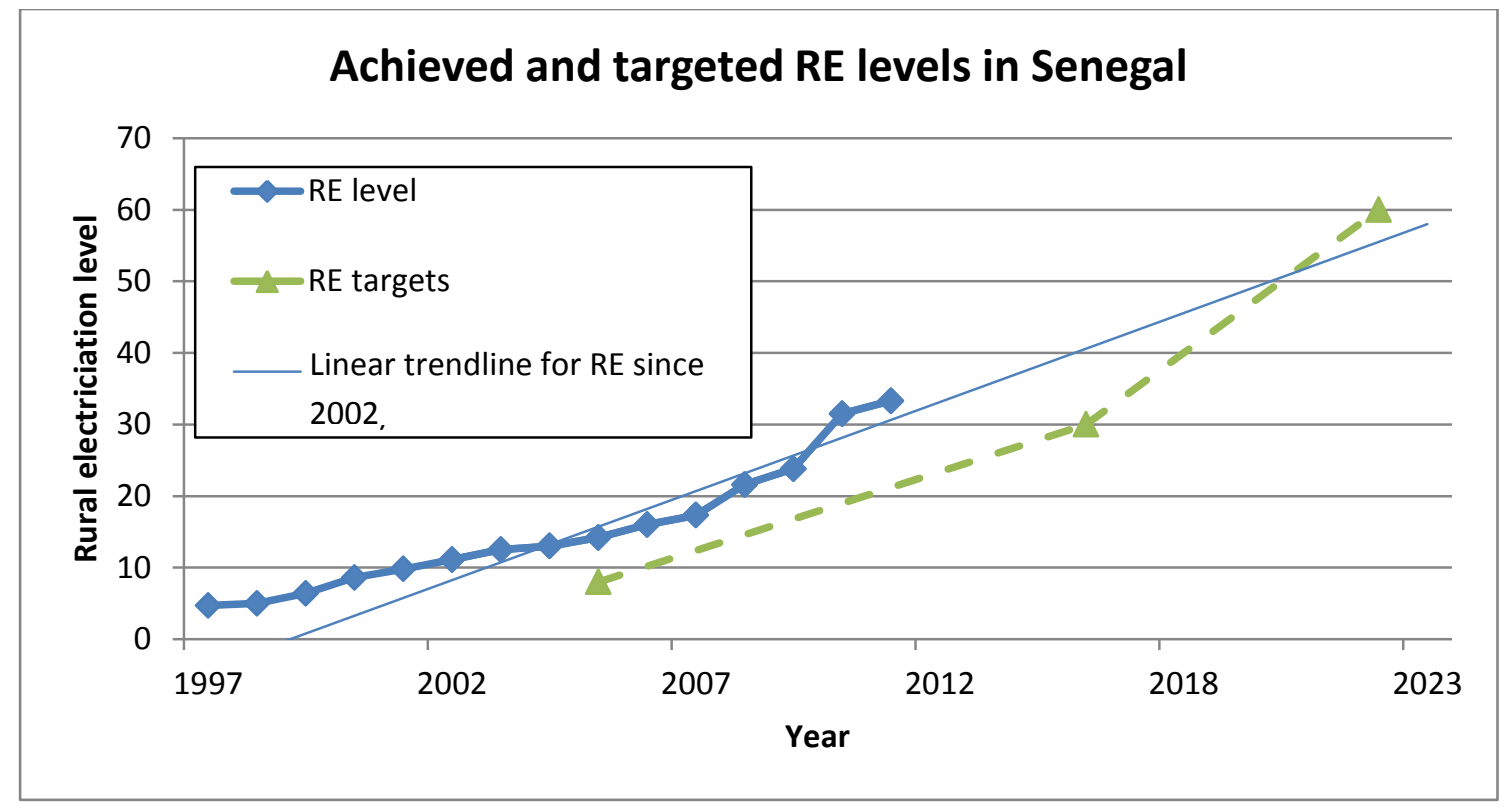

Figure 1 Achieved and targeted RE levels in Senegal.

Source data: (IEA, 2013; IEA, 2012; SIE, 2012; GoS, 2011; Dufail, 2010; Gaye, 2010; GoS, 2006b).

Notes: Achieved levels of RE compiled from multiple sources which may not have used the same parameters. Data for 2012 were not available at the time of writing.

The progress illustrated in Figure 1 suggests at first glance that PASER has indeed been successful, that the reforms described in section 3.2 have borne fruit. However the role of PASER in delivering electrification is rather less remarkable. Table 2 summarises the developments of PASER's programmes to August 2012, representing the first decade of the Plan's activities. Only one programme, the Priority Programme, finalised its organisational and legal framework during this period. No new household connections were completed through any of the 'official' programmes. 6,121 households were electrified through pilots of the Local Initiative, and the installation of hardware (but not final connections) was completed for 5,000 homes under the Priority Programme. 
Table 2 Summary of PASER programme developments to August 2012.

Sources: (Sarr, Personal communication-b; Sarr, Personal communication-c; ASER, 2012a; ASER, 2012b; ASER, 2012d; ASER \& DESI, 2012; Business 1, 2012; Business 3, 2012; Business 4, 2012; Business 5, 2012; Civil servant 9, 2012; Donor 1, 2012; Donor 3, 2012; Government 4, 2012; Government 5, 2012; Government 7, 2012; Ndiaye, 2011; Niang, 2011).

\begin{tabular}{|c|c|c|c|}
\hline & Priority Programme & Local Initiative & $\begin{array}{l}\text { Multi-sector } \\
\text { Programme }\end{array}$ \\
\hline $\begin{array}{l}\text { Development of } \\
\text { organisational and } \\
\text { legal framework }\end{array}$ & Completed. & Ongoing. & $\begin{array}{l}\text { As for Priority } \\
\text { Programme and Local } \\
\text { Initiative. }\end{array}$ \\
\hline $\begin{array}{l}\text { Development of } \\
\text { documentation and } \\
\text { processes }\end{array}$ & Ongoing. & Ongoing. & Ongoing. \\
\hline Selection of projects & $\begin{array}{l}10 \text { concessions } \\
\text { defined. }\end{array}$ & $\begin{array}{l}2 \text { 'top down' pilot } \\
\text { projects selected. } 1 \\
\text { 'full' non-pilot project } \\
\text { selected. Difficulties } \\
\text { attracting 'bottom up' } \\
\text { projects. }\end{array}$ & $\begin{array}{l}\text { No projects linked to } \\
\text { Priority Programme or } \\
\text { Local Initiative } \\
\text { selected. } 7 \\
\text { independent projects } \\
\text { selected. }\end{array}$ \\
\hline Donor funding & $\begin{array}{l}\text { Secured for } 6 \\
\text { concessions. }\end{array}$ & $\begin{array}{l}\text { Secured for } 1 \text { full } \\
\text { project. General } \\
\text { delays in attracting } \\
\text { funding. }\end{array}$ & $\begin{array}{l}\text { Secured for } 7 \\
\text { independent projects. }\end{array}$ \\
\hline Selection of IPPs & $\begin{array}{l}\text { Selected for } 6 \\
\text { concessions. Contracts } \\
\text { signed for } 3 \\
\text { concessions. }\end{array}$ & $\begin{array}{l}\text { Selected for } 1 \text { full } \\
\text { project. }\end{array}$ & $\begin{array}{l}\text { Selected for } 7 \\
\text { independent projects. }\end{array}$ \\
\hline $\begin{array}{l}\text { Technical } \\
\text { specifications }\end{array}$ & Ongoing negotiations. & Ongoing negotiations. & Ongoing negotiations. \\
\hline Installation works & $\begin{array}{l}\text { Completed for 5,000 } \\
\text { households in first } \\
\text { concession only. }\end{array}$ & $\begin{array}{l}1^{\text {st }} \text { pilot scheme } \\
\text { completed: } 1,894 \\
\text { households. } 2^{\text {nd }} \text { pilot } \\
\text { scheme underway: } \\
8,663 \text { households. In } \\
\text { total } 6,121 \\
\text { connections completed } \\
\text { by August } 2012 \text {. No } \\
\text { 'full' projects. }\end{array}$ & None. \\
\hline $\begin{array}{l}\text { Electricity } \\
\text { connections } \\
\text { completed }\end{array}$ & $\begin{array}{l}\text { None - awaiting } \\
\text { resolution of tariff } \\
\text { negotiations. }\end{array}$ & As above. & None. \\
\hline
\end{tabular}

The 6,121 households electrified through pilot projects are estimated to represent $4 \%$ of new connections realised since PASER's inauguration and less than $1 \%$ of total rural electricity connections in Senegal ${ }^{6}$. The mismatch between this figure and the overall rise in RE over the period indicates that PASER has not been the primary driver of RE, and that it has not met its

\footnotetext{
${ }^{6}$ Senegal's RE level increased from 11.1\% in 2002 (SIE, 2012) to 22.2\% in 2011 (IEA, 2013). Assuming the number of rural households has remained constant at 730,000 (Gueye, 2009), it can be estimated that the increase represents 162,060 new household connections, of which 6,121, or $4 \%$, by PASER.
} 
objectives to increase RE levels. The vast majority of new connections have been the product of supplementary initiatives such as covenants, the Emergency Programme and independent projects.

PASER's slow material progress threatens to undermine the interest that the Plan has attracted from investors. All of the Priority Programme's donors have all expressed dissatisfaction with its slow progress (Donor 1, 2012; Donor 3, 2012; KfW, 2010; DECRS, 2009). The disbursement deadlines for the first concessions have had to be extended by several years, but there are fears that the extensions may be too short to allow disbursement of the full level of funding promised - and further extensions are not expected (Donor 1, 2012; Government 8, 2012). This adversely impacts the propensity of donors to fund additional ASER projects; one donor has already refused to finance a second concession on these grounds (Donor 3,2012). IPPs already involved with the Priority Programme are similarly frustrated by its slow development (Business 3, 2012; Business 4, 2012).

Further there are concerns that IPPs may have offered overly generous bids in order to gain a foothold in Senegal's RE sector (Business 4, 2012; Mostert, 2008). ONE and Isofoton - the only IPPs to hold two concessions - both provided a significantly more attractive bid for their first concession (Table 1). In some cases IPP investments in the Priority Programme are expected to be less profitable than other business activities, and some IPP investments are thought to be motivated by corporate social responsibility and the desire to improve international relations (Business 3, 2012; Business 4, 2012). Below-cost bids are obviously not viable if repeated widely, and the perceived value of 'soft' social responsibility/international relations benefits may decrease as private investment in the sector becomes more common. The invitations to tender for the Priority Programme received only a small number of responses, further suggesting that private interest is limited (Government 10, 2012). The remaining concessions may find it more difficult to attract high levels of private finance.

\section{Results - What has held PASER back?}

\subsection{Introduction}

PASER's implementation has been much slower than anticipated, much to the frustration of many of the stakeholders interviewed in our research. In what follows we investigate the underlying causes of the delays, based upon the factors suggested by interviewees. These can be grouped thematically as factors relating to innovation, politicisation, inter-institutional tensions, and policy inertia.

\subsection{Policy and process innovation}

\subsubsection{The pace of institutional innovation}

Many of PASER's organisational, procedural, legal, regulatory and financial aspects have had to be developed from scratch, having no precedent amongst either Senegalese or World Bank projects. As such they have taken time to implement. Development of the first Priority Programme concession is considered to have been particularly slow (Consultant 3, 2012; Donor 1, 2012; Government 1, 2012; Government 7, 2012). Even in 2012 the finalisation of the Priority Programme's first connections were stalled by extensive negotiations to resolve a conflict between the desire for flat-rate monthly 
electricity fees (which facilitate consumer payments), and the need for IPPs to be protected from uncompensated wasteful consumption (Business 4, 2012).

Although ASER has made considerable efforts to design an effective RE strategy some mistakes have inevitably been made, with resultant delays. For example, a requirement that the details of Multisector Programme projects be finalised before the commencement of Priority Programme installation works contributed to a year-long delay when a Multi-Sector project developer resigned (Government 4, 2012). It is also thought that adoption of a smaller number of larger Priority Programme concessions would have streamlined administration, reducing delays (Government 4, 2012).

\subsubsection{Stakeholder participation}

The development and implementation of PASER has incorporated extensive stakeholder consultations in a bid to create programmes that are practicable, equitable and well-supported. However, some interviewees perceive the consultations to be unnecessarily thorough and very timeconsuming (Consultant 3, 2012; Donor 1, 2012; Government 1, 2012; Government 10, 2012). For example the process to develop and tender Priority Programme concessions involves eight different groups of consultees and seven separate consultations. These were originally expected to account for 130 days of a year-long process (World Bank, 2004). In reality the development of the first concession took five years, with extensive negotiations between stakeholders blamed for long delays (Government 1, 2012).

\subsubsection{Limitations to technical capacity}

Several interviewees are concerned that limitations to the technical capacity of ASER and the wider Senegalese energy sector may have slowed PASER's development (Business 3, 2012; Consultant 4, 2012; Government 6, 2012). It has been suggested that individuals with limited technical knowledge may not be equipped to comparatively assess different options, making them either dependent on trusted external advisors (Consultant 4, 2012) or resistant to abandoning already-understood (but potentially inefficient) options (Business 3, 2012; Business 4, 2012). Certain technical negotiations are considered to have been unnecessarily lengthy, even when the proposed alterations were technically appropriate and eventually adopted (Business 3, 2012; Government 1, 2012; Government 8, 2012).

\subsection{Politicisation}

Fluctuating political support is considered to have been a major hindrance to PASER's development (Business 5, 2012; Consultant 4, 2012; Consultant 5, 2012; Donor 3, 2012; Government 8, 2012). Some officials are thought to have been privately opposed to the structural solutions of 1998 reforms, but to have followed them in order to access finance from the World Bank and the IMF (Consultant 4, 2012; Government 8, 2012; Gökgür \& Jones, 2006).

The Ministry of Energy appoints the Managing Director of ASER and therefore has direct influence over the implementation of its plans and programmes. Several interviewees believe that some of ASER's staff - especially those at a senior level - were recruited to support the (then) current political regime rather than for their technical and professional merits (Business 3, 2012; Consultant 4, 2012; Consultant 5, 2012). Such appointments may have made it easier for ASER to focus its efforts on the Emergency Programme (discussed in section 4.5), or for the Ministry to delay support to ASER in 
disputes with Senelec (discussed in 4.4). Changes to the Agency's senior management are thought to have disrupted PASER's implementation. The Managing Director changed five times over 20022012 (Mawhood, 2012), with the second and third changes of leadership thought to have involved considerable realignments of policy (Government 8, 2012). Further, two Managing Directors have been accused of embezzlement at the Agency (Ndoye, 2013; Diatta, 2012), damaging ASER's reputation with would-be partners (Donor 1, 2012).

$\mathrm{RE}$ is frequently in the Senegalese public eye, and as such lends itself to political exploitation. Recent years have seen repeated media scrutiny of ASER due to allegations of fraud and the World Bank's criticism of the Plan's slow progress (see for example, SeneNews (2010), Faye (2012), Guèye (2012)). The political importance of the issue is demonstrated by the government's repeated commitments to ambitious, highly-publicised (perhaps unrealistic) RE targets (Mawhood, 2012). However, the attraction of a positive public RE discourse does not necessarily increase political motivation to action improvements. Senegal's rural population are considered to have been less politically active historically on energy issues than their urban counterparts (Donor 1, 2012). Some politicians have therefore prioritised the resolution of urban, rather than rural, energy issues; in the RE arena promised action may count more than results delivered (Business 3, 2012; Consultant 4, 2012; Donor 3,2012 ). The situation is now beginning to change with rural populations becoming more politically active; this may increase political interest in realising improvements (Government 8, 2012)

\subsection{Inter-institutional tensions: Senelec and ASER}

Prior to the 1998 reforms Senegal's main RE efforts were conducted by Senelec through covenants with the government. Senelec made a significant loss on the covenants, offset by cross-subsidisation with urban clients. It was recognised that cross-subsidisation would not be able to support a high level of RE penetration (Government 5, 2012; Government 6, 2012; Hoang-Gia, 1998).

The creation of a separate RE agency should therefore have been regarded as a benefit to Senelec. It divested the company of its costly RE responsibilities, promised to bolster Senelec's revenue streams (through ambitious grid expansion), and reduced the risks and costs to Senelec of operating in the rural domain (through trade with a small number of IPPs, rather than thousands of householders) (Government 8, 2012). Despite this several interviewees believe that Senelec resented ASER's creation (Consultant 3, 2012; Consultant 4, 2012; Government 5, 2012; Government 8,2012 ). ASER seems to have been viewed not as an organisation relieving Senelec of costly obligations, but one that appropriated part of its former work stream and income. As we discuss below, interviewees also argue that the Ministry of Energy appeared often to favour the interests of Senelec over those of PASER.

Senelec's negative perception of PASER can be understood in light of the wider impacts of the 1998 reforms, of which Senelec's privatisation was intended to be a cornerstone. The company was partially privatised for 18 months over 1999-2000, but renationalised due to disputes between the purchaser and the newly elected government. A second attempt to privatise Senelec in 2001 was abandoned because a deal could not be agreed with either of the two preferred bidders (Gökgür \& Jones, 2006). Senelec's employees thus experienced significant disruption, but efforts to garner their support for the changes were limited. Existing staff were consulted very little prior to or during privatisation, and company shares that had been earmarked for staff were never offered to employees (ibid.). An apparent influx of expatriates to senior positions during privatisation was 
resented by the national workforce, which was itself significantly reduced after 1998 (ibid.). PASER's public-private-partnership model was a separate element of the reforms, but several interviewees suggest that some members of Senelec may have viewed it as a threatening new attempt at privatisation by the back door (Consultant 3, 2012; Consultant 4, 2012; Government 5, 2012; Government 8, 2012).

The relationship between ASER and Senelec is considered to have improved in recent years (Government 5, 2012; Government 8, 2012). However some company members continue to believe that RE should have remained within Senelec's remit (Government 3, 2012; Government 6, 2012). One disagreed with private execution of RE (being an unprofitable activity) (Government 3, 2012); another argued that the RE Plan would have been less problematic under the auspices of a single electricity provider (Government 6, 2012). Both think that PASER would be more cost-effective if delivered by Senelec, and view RE as an activity that should be publicly-managed. Although not representative of Senelec's organisational views, this demonstrates that some members of the company still privately disagree with the very premise of ASER.

\subsubsection{Senelec, PASER and the Ministry of Energy}

The strained nature of the relationship between ASER and Senelec is widely acknowledged (Consultant 4, 2012; Government 1, 2012; Government 8, 2012). The combination of a Senelec that felt threatened by ASER's creation and fluctuating ministerial support for PASER's strategy seems to have provided a breeding-ground for protracted disputes. Several interviewees think that Senelec has actively created obstacles to PASER's progression (Consultant 3, 2012; Consultant 4, 2012; Government 5, 2012; Government 8, 2012). Cited examples include:

- The Ministry of Energy had to intervene to resolve stalled negotiations about the boundaries of the two organisations' electricity distribution territories, because Senelec was reluctant to cede part of its territory (Donor 1, 2012).

- Senelec refused to sign power-purchase agreements with private operators wishing to participate in the Emergency Programme, however was quick to sign such an agreement with its subsidiary (Donor 1, 2012; Government 5, 2012).

- Since 2006 Senelec has refused to collect and transfer 'rural electrification payments' from its customers to ASER (Consultant 4, 2012; Government 8, 2012), despite being legally required to do so (GoS, 2006a).

Since ASER and Senelec are both overseen by the Ministry of Energy one would expect there to be pressure for the two organisations to cooperate. The Ministry has intervened to end disputes in several instances, although only after these continued for several months (Business 4, 2012; Government 1, 2012; Government 8, 2012; Government 10, 2012). It may be that the Ministry of Energy is reluctant to intervene because it fears the power wielded by Senelec's strong staff union (Government 8, 2012). The union has previously called protracted strikes, for example in resistance to Senelec's proposed privatisation (ibid.). Government concern about the outcry that might follow resultant electricity disruptions is very understandable in light of recent public protests about power-cuts ${ }^{7}$. Alternatively, in the case of RE payments, it may be that the Ministry of Energy has not

\footnotetext{
${ }^{7}$ Senegal's electricity grid has suffered frequent, long-duration power-cuts since the 1998 energy sector reforms (Fofana, 2011; Dabo, 2006; Dioh, 2003). In 2011 these led to violent protests on the streets of Dakar
} 
pressed Senelec for collection because it fears popular objection. In addition the incentives for the Ministry to actively support ASER rather than Senelec in disputes are weak: ASER does not have the strength in numbers to protest on the same scale as Senelec, nor would a strike disrupt essential public services and risk angering the population. The fact that Senelec has been able to disrupt PASER repeatedly and apparently without penalty appears consistent with the notion that there is at least some incentive for the government to turn a blind eye to its actions. ASER's programmes have suffered serious delays as a result and the Agency has been denied the rural electrification payments it is due by statute.

\subsection{Policy inertia}

The Rural Electrification Emergency Programme is not part of PASER, but was one of ASER's major programmes over 2008-2012. It aimed to electrify 473 villages, with works for 100 being managed by ASER (cost $\$ 4.7$ million), and 373 by Senelec ( $\$ 19.3$ million $^{8}$ ) (Thioune, 2012; Sylla, 2011). Electrification projects have been realised rapidly under the programme, however the aggregate number of connections is not considered "significant" in comparison to PASER's ambitions (Donor 1, 2012). There is widespread belief amongst interviewees that the Emergency Programme was driven by political pressure to achieve short-term RE improvements in the face of the slow progress of PASER (Consultant 3, 2012; Government 1, 2012; Government 3, 2012; Government 8, 2012). This hypothesis is supported by observations that RE efforts under the Emergency Programme increased immediately prior to elections (Government 3, 2012; Government 6, 2012).

Several interviewees view the Emergency Programme as a regression to Senegal's historical RE model (Business 1, 2012; Consultant 3, 2012; Donor 1, 2012; Government 5, 2012; Government 8, 2012). Like Senegal's historical covenant model the Programme is state-funded, with villages to be electrified being state-selected. In addition the Emergency Programme is considered to have exacerbated PASER's difficulties by diverting resources (World Bank, 2012a). Reliance on this model indicates that PASER's more progressive characteristics have not been uniformly prioritised by those setting ASER's agenda. This concerns interviewees, who believe that the technical and financial structures of PASER are better equipped (than the Emergency Programme) to realise a critical mass of new electricity connections, and to encourage sustainable, longer-term investment in RE by private entities (Business 1, 2012; Consultant 3, 2012; Donor 1, 2012).

\subsection{Summary}

PASER has experienced significant delays during the first decade of its operation for a variety of reasons, grouped thematically in this analysis. The development and implementation of innovative policy and process frameworks such as PASER is inherently challenging and has been timeconsuming. The Plan's thorough stakeholder consultations have taken longer than anticipated, and technical negotiations may have been prolonged by limitations in local expertise. Politicisation, apparently manifested through political staff appointments, high profile (and sometimes negative) media coverage, and inconsistent government support, is also widely thought to have exacerbated PASER's difficulties. The Plan has further suffered the effects of tensions between Senelec and ASER.

(Jeune Afrique, 2011) and were a key issue leading up to the 2012 presidential elections (Agence France Presse, 2012; Carayol, 2011).

${ }^{8}$ Estimated based on figures from Thioune (2012) and Sylla (2011). 
Interviewees suggest that some Senelec employees are opposed to the privatisation which PASER represents and therefore perceive it as a threat. Senelec seems to have actively blocked PASER's progression, and ministerial support for ASER has been withheld during disputes between the two organisations. Finally, ASER's institutional capacity has been compromised by policy inertia. The values inherent to PASER have not been applied to concurrent programmes, diverting resources from the Plan.

\section{Discussion - Comparison between Senegal's experience and international experiences with reform-based rural electrification}

\subsection{Introduction}

PASER is one of many RE initiatives developed as a result of electricity sector reforms in SSA. As we will discuss below, the specific obstacles that have stalled PASER resemble troubles that have hindered other such initiatives. Whilst the Plan has effectively targeted one major barrier to energy access - lack of finance - many others remain to be addressed.

\subsection{Impacts of reform-based rural electrification in SSA}

Power sector reforms in SSA have often focussed on the resolution of problems affecting the existing electricity infrastructure, rather than expansion of services to rural and low-income groups (Onyeji, Bazilian \& Nussbaumer, 2012; GNESD, 2004; Wamukonya, 2003; Karekezi \& Kimani, 2002). Their impacts on RE have been mixed (Besant-Jones, 2006; GNESD, 2004). Although some countries have realised considerable improvements (for example Botswana, South Africa and Zimbabwe) (Prasad, 2008; Davidson \& Mwakasonda, 2004), many others have seen only limited benefits, with the overall impact on the rural population being detrimental in some instances (for example Kenya, Zambia, Mali, Senegal) (Onyeji, Bazilian \& Nussbaumer, 2012; Haanyika, 2006; Sokona, Sarr \& Wade, 2004; Wamukonya, 2003; Karekezi \& Kimani, 2002). Where impacts have been positive, RE has nonetheless tended to progress more slowly than suggested by initial projections, and more slowly than in countries able to rely on state resources (and thus avoid reforms) (Ahlborg \& Hammar, 2012; Massé, 2010; Mostert, 2008).

Several authors attribute the differences in outcomes of reform-based initiatives to the inclusion or exclusion of explicit governmental commitments to RE within the wider reforms (Onyeji, Bazilian \& Nussbaumer, 2012; GNESD, 2004; Karekezi \& Kimani, 2002). However, this does not explain PASER's poor performance. The 98-29 Electricity Reform Law stated RE as one of its principal aims and mandated the creation of a RE agency (GoS, 1998).

\subsection{Resistance towards electricity sector reforms}

Donor conditionality affords little choice to poor countries with ambitious development strategies, if the alternative is to limit electrification to a rate affordable with state funds (Kouassi \& Pineau, 2011; Massé, 2010). Although some governments have embraced liberalisation, widespread resistance towards power sector reforms has been observed across SSA at both the organisational and personal level (Ahlborg \& Hammar, 2012; Boubou, Watchueng \& Massé, 2010; Estache, 2006). Many African policymakers are sceptical of applying lessons learned from reforms in non-African regions to their own countries, due to their very different socioeconomic and political circumstances (Government 1, 
2012; Turkson \& Wohlgemuth, 2000). State authorities and national utilities in several countries have been reluctant to accept privatisation (Boubou, Watchueng \& Massé, 2010; Karekezi \& Kimani, 2002), with labour unions mounting oppositional campaigns in West Africa (including Senegal) (Gökgür \& Jones, 2006; Karekezi \& Kimani, 2002). Many decision-makers disagree with the premise of subsidising investments led by the private sector (Boubou, Watchueng \& Massé, 2010; Gökgür \& Jones, 2006). Stakeholders in Tanzania and Mozambique have been noted not to understand the motivation for private companies to participate in RE (given its poor profit margins) (Ahlborg \& Hammar, 2012), a perspective shared by at least some employees of Senelec as we explain above (see section 4.4).

The disappointing results of schemes based on privatisation to date has led CLUB-ER, a consortium of RE bodies in SSA, to advocate that public bodies resume a more significant role in the sector (Boubou, Watchueng \& Massé, 2010; Massé, 2010). Governments of several countries have already taken action in this manner, increasing state investment and in some instances subsidising the entire cost of projects in order to bolster electrification results (Boubou, Watchueng \& Massé, 2010; Mostert, 2008) and of course Senegal's Emergency Programme is an example.

\subsection{Development of new frameworks: a lengthy process}

Development and implementation of a functional, novel sectoral framework is a lengthy process. Protracted negotiations and slow bureaucratic procedures have been observed in several countries, as well as Senegal:

- Mismatched donor reporting requirements increased the administrative load of RE for public authorities in Tanzania, thus slowing overall progress (Ahlborg \& Hammar, 2012).

- Poor communication between stakeholders caused confusion and delays in the early stages of RE schemes in Mozambique (Ahlborg \& Hammar, 2012).

- Lengthy consultation between the rural electrification agency, government, consultants, and the World Bank have stalled implementation of projects under Uganda's 'Energy for Rural Transformation' programme (Mostert, 2008).

Delays related to stakeholder negotiations are considered to have been particularly common in programmes financed by the World Bank, due to the Bank's procurement rules (Mostert, 2008).

In some instances negotiations have been slowed by gaps in local technical expertise, as consultees are ill-equipped to comparatively assess options. In Senegal IPP proposals to diverge from European industry standards have provoked delays of up to four years (Business 3, 2012; Business 4, 2012; Mawhood, 2012), while in Burkina Faso the introduction of Single Wire Earth Return (SWER) technology had to surmount the considerable scepticism of Burkinabe engineers (Mostert, 2008). South Africa's ESKOM was eventually appointed to provide technical training to consultants in Burkina Faso (ibid.).

\subsection{Inconsistent political support}

Strong, sustained political support is crucial for ambitious RE programmes, since governments are responsible both for creating a sufficiently attractive investment environment and for ensuring policy targets marginalised customers (Onyeji, Bazilian \& Nussbaumer, 2012). However, faced with numerous urgent socioeconomic demands, and given the relative expense and investment risk of RE, 
many Sub-Saharan governments have not prioritised spending in the area (Onyeji, Bazilian \& Nussbaumer, 2012; Massé, 2010). Further, efforts to streamline energy access projects have been hampered by political meddling. Government officials and private sector companies have been accused of corruption and collusion in projects led by IPPs in Kenya, Tanzania, Uganda and Zimbabwe (Karekezi \& Kimani, 2002) as well as Senegal (Joe, 2013; Diatta, 2012). Electoral ambitions are thought to influence the selection of communities to be electrified in Tanzania and Mozambique (Ahlborg \& Hammar, 2012) and under Senegal's historical electrification model (Government 3, 2012).

\subsection{The significance of institutional factors}

Institutional issues are widely considered important to the performance of policy (Nicholls et al., 2014; Gupta et al., 2007), particularly in developing countries (Barnes, 2007; Bell, 2002). Econometric analyses have further found that the 'level of institutional development' and 'government effectiveness' have a significant impact on RE levels in SSA specifically (Onyeji, Bazilian \& Nussbaumer, 2012; Nanka-Bruce, 2010). Despite this policy design and evaluation commonly neglect the effects of political processes and institutional operations, leading to unrealistic expectations of policy performance (Nicholls et al., 2014; Ilskog \& Kjellström, 2008). Substantial empirical research has demonstrated that incompatibility between policy design and the institutional environment is a key cause of dissonance between anticipated and realised policy outcomes (Theesfeld, Schleyer \& Aznar, 2010).

Such issues appear to have affected PASER. The Plan has failed to realise new electricity connections as predicted, and its stakeholders largely attribute delays to institutional difficulties. Other experiences with reform-led RE reflect, to some extent, the failures of broader power sector reforms. Many attempts at privatisation in developing countries have had limited success (Rosenzweig, Voll \& Pabon-Agudelo, 2004). Causal factors are thought to include: lack of ideological buy-in by local stakeholders; imposition of 'state of the art' structures designed for well-functioning, mature electricity sectors in dysfunctional, immature ones; fear of wavering political support, leading reforms to be pushed through too rapidly; and the assumption that the power sector overseeing the reforms already has the characteristics and capabilities expected in an alreadyreformed sector (Rosenzweig, Voll \& Pabon-Agudelo, 2004; Wamukonya, 2003). In short, reformers have failed to appreciate the political and organisational realities of the sector being restructured.

\subsection{Finance}

PASER has been highly successful in attracting offers of finance. Many public-private-partnership RE models elsewhere have struggled to secure funding from either donors or the private sector (Ahlborg \& Hammar, 2012; Massé, 2010; Mostert, 2008).

The lack of donor interest in other projects is attributed to a number of factors. In several instances national ambitions to increase $\mathrm{RE}$ and/or readiness to commit state funds have been insufficient to attract donor contributions (Massé, 2010; Mostert, 2008). There are also concerns that a number of international financial instruments are not well adapted to support initiatives based on the commonly-used Rural Electrification Agency/Fund model, of which PASER is an example (Massé, 2010). In particular instruments are not always equipped to identify and support private electrification companies or to fund more innovative and/or smaller electrification schemes (ibid.). 
Even where initial donor funding has been secured, Rural Electrification Agency/Fund initiatives have tended to be slow to develop and realise connections, discouraging investment in subsequent programmes (ibid.). It is worth noting that PASER itself benefitted from two rounds of investment from the World Bank (Table 1), which was directly involved in designing and developing the Plan, and hence a major supporter.

The lack of private investment is blamed in part on the design of Rural Electrification Agencies/Funds themselves, many of which are essentially mechanisms to obtain and redistribute subsidies. They often lack the capacity to access sources of finances utilised by the wider electricity sector and infrastructure projects in SSA (Boubou, Watchueng \& Massé, 2010; Massé, 2010). Even those with such capabilities (and partnering IPPs) have had little success in securing finance from conventional sources (Massé, 2010), due both to the perceived investment risk of RE and to regulations which prevent commercial banks from supplying long-term loans in many African countries (Mostert, 2008). PASER may have had an advantage in this respect, since Senegal is considered politically stable with improving economic prospects (section 3.1), and thus represents a less risky investment environment. Across SSA concession-holders have tended to rely on loans and subsidies from the RE agencies themselves rather than seeking private funds to support their investments (Massé, 2010).

\section{Conclusions and policy implications}

PASER was developed within the framework of power sector reforms in Senegal, themselves implemented in part at least to qualify for donor finance. This is a common background to national RE initiatives in SSA.

Conceptually the PASER model offers an efficient means of increasing private investment in RE, using technology-neutral output-based subsidies as a leveraging mechanism to make RE commercially viable and to incentivise effective electrification solutions. This innovative design has attracted very significant support from donor organisations and major electricity players, with an average of $49 \%$ of the capital investment for Priority Programme concessions being privately-sourced. Experiences with privatisation-led RE models elsewhere underline the unusualness of the scale of financial support promised. Whilst most of PASER's funds are yet to be disbursed, many countries struggle to secure even offers of finance. PASER's financial success demonstrates the potential of this policy model to attract extensive private funds, however given the significant variation in national investment conditions across SSA it is unlikely to be uniformly suitable throughout the region.

PASER's results in terms of installations are far less impressive: in ten years PASER realised 6,121 electricity connections, representing an increase of less than $1 \%$ in national RE levels. This slow progress has disappointed stakeholders and threatens to undermine PASER's future viability, with potential withdrawal of funds being a real concern. The Plan's early objectives included increasing the national RE level from $5 \%$ in 1997 to $8 \%$ by 2005 and $30 \%$ by 2015 and $60 \%$ by 2022 . Whilst RE in Senegal has to date exceeded these targets, the new electricity connections are predominantly the result of more conventional programmes and not PASER.

The influence of institutional factors on policy performance in developing countries is wellrecognised, yet policies are frequently developed without realistic consideration of the extant institutional circumstances. This seems to have been the case for PASER, which was described by 
one interviewee as "the perfect example of a thing that works very well on paper, but doesn't work on the ground" (Donor 3, 2012). Overall the Plan has faced significant (largely institutional) barriers over the past decade, with stakeholders citing delays arising from organisational opposition, inconsistent ministerial support, protracted consultations and the inherent challenges of implementing an innovative policy framework. Early expectations for the speed and scale of PASER's implementation were unrealistic, and the importance (or lack) of widespread stakeholder approval underestimated. Moreover ASER's institutional capacity has been compromised by inconsistent political commitment to creating a well-governed, technically-focussed organisation with a clear, consistently-applied RE strategy. The values inherent to PASER have not been applied to concurrent programmes (apparently diverting resources from the Plan), and ministerial assistance seems to have been withheld at times of need. Such difficulties underline the importance of tailoring policy to fit with the realities of the institutional and political environment. Similarities between PASER's experiences and those of electrification initiatives across SSA demonstrate the wider relevance of this issue. Whilst PASER's successes in garnering external support and fundraising are noteworthy, it has not succeeded in resolving institutional barriers to delivery that are common in the region.

The difficult relationship between ASER and Senelec further illustrates both the sensitivity of individuals to organisational restructuring and the power that individuals may wield within an organisation. Where instigation of a new policy strategy will alter the revenue streams and/or responsibilities of existing structures, care needs to be taken to effectively communicate the purpose of reforms and to incentivise incumbents to cooperate with new institutions. In situations where governance is suspected to be weak, early consultation could help to anticipate problems by investigating likely reactions to reforms and their secondary impacts.

More generally, radical policy reforms are unlikely to achieve rapid results in countries with limited resources - and may not even represent a suitable approach to RE. RE initiatives based on major sectoral reforms have tended to progress slowly in SSA. This is not surprising given the scale and complexity of implementing a new institutional, market-based structure, and the political vulnerabilities and limits to organisational capacity that are known to affect much of the region. Some authors have questioned the wisdom of imposing radical reforms on such immature electricity sectors, however alternative options to finance electrification efforts are not obvious. If reformbased approaches are to be practicable they must be based on a clear, realistic appraisal of the characteristics, capabilities and weaknesses of the existing RE sector. They should not be regarded as a policy 'quick fix', but a long-term approach that will require significant, ongoing transitional support.

\section{Acknowledgements}

We are very grateful for the insights and cooperation of the staff of ASER, of all of the anonymous stakeholder interviewees, and of the International Institute for Sustainable Development. We further thank the Sambou-Bodian family and SEMIS Energy Services in Sahelian Environment for their gracious hospitality. This project was facilitated by the financial support of the UK Energy Research Centre - International Renewable Agency (UKERC-IRENA) collaboration, funded by the UK 
Department of Energy and Climate Change. It is based on Rebecca Mawhood's MSc thesis in Environmental Technology at Imperial College London.

\section{References}

AFD. 2012. Projet PASER Tamba [Online]. Available: http://www.afd.fr/baseprojets/consulterProjet.action?idProjet=CSN6032 [Accessed 3rd October 2012].

AfDB 2010. Committee of Ten Policy Brief: Financing of Sustainable Energy Solutions. Washington DC: AfDB.

Agence France Presse. 2012. Sénégal: Laurent Fabius salue "I'exemple" du mouvement "Y'en a marre". Jeune Afrique, 28th July. Available: http://www.jeuneafrique.com/actu/20120728T082029Z20120728T082027Z/]

Ahlborg, H. \& Hammar, L. 2012. Drivers and barriers to rural electrification in Tanzania and Mozambique - Grid-extension, off-grid, and renewable energy technologies. Renewable Energy.

ANSD. 2012. Les indicateurs clés sur le Sénégal [Online]. Agence Nationale de la Statistique et de la Démographie. Available: http://www.ansd.sn/senegal indicateurs.html [Accessed 8/9/2012 2012].

ASER. 2012a. Agence Sénégalaise d'Electrification Rurale [Online]. ASER. Available: http://www.aser.sn/ [Accessed 5th June 2012].

ASER 2012b. ERIL situation des realisations - 1 août 2012. [Excel spreadsheet]. Internal ASER document.

ASER 2012c. Rapport de passation de service sur le Fonds d'Electrification Rurale. Dakar, Senegal: Internal ASER document.

ASER 2012d. Situation des concessions et planification objectif 60\% de taux E.R. au Sénégal à I'horizon 2017 - juillet 2012. [Excel spreadsheet]. Internal ASER document.

ASER \& DESI. 2012. Électrification rurale au Sénégal - Découpage des concessions ER - Janvier 2011. ASER.

Barnes, D. F. (ed.) 2007. The Challenge of Rural Electrification. Strategies for Developing Countries, Washington D.C.: Resources for the Future.

BBC. 2012. Senegal profile [Online]. BBC. Available: http://www.bbc.co.uk/news/world-africa14093674 [Accessed 28th August 2012].

Bell, R. G. R., C. 2002. Environmental policy for developing countries. Issues Sci. Technol., 18, 63-70.

Besant-Jones, J. 2006. Reforming Power Markets in Developing Countries: What Have We Learned? Washington D.C.: Energy Sector and Mining Board, World Bank.

Boubou, P., Watchueng, S. \& Massé, R. 2010. Public-Private Partnership in rural electrification programs in Africa. Francheville, France: Club-ER.

Bryman, A. 2008. Social Research Methods, New York, N.Y., Oxford University Press.

Business 1. 5 July 2012. Interview with Rebecca Mawhood.

Business 3. 11 July 2012.Interview with Rebecca Mawhood.

Business 4. 27 July 2012.Interview with Rebecca Mawhood.

Business 5. 31 July 2012.Interview with Rebecca Mawhood.

Carayol, R. 2011. Sénégal : Wade peut-il encore gagner en 2012 ? Jeune Afrique, 27th September.

Available: http://www.jeuneafrique.com/Article/ARTJAJA2646p034-037.xml0/oppositionpresident-karim-wade-macky-sallsenegal-wade-peut-il-encore-gagner-en-2012.html] 
Civil servant 9. 2nd August and 8th August 2012.Interviews with Rebecca Mawhood.

Consultant 3. 29 June 2012.Interview with Rebecca Mawhood

Consultant 4. 3 July 2012. Interview with Rebecca Mawhood.

Consultant 5. 4 July 2012.Interview with Rebecca Mawhood.

Dabo, B. 2006. REPRISE DES COUPURES DE COURANT - La Sénélec se perd dans ses explications.

SeneWeb News, 7th December. Available:

http://www.seneweb.com/news/Economie/reprise-des-coupures-de-courant-la-s-n-lec-seperd-dans-ses-explications $\mathrm{n}$ 7083.html]

Davidson, O. \& Mwakasonda, S. 2004. Energy Access theme results: Electricity Access in South Africa and Zimbabwe. Cape Town, South Africa: Energy Research Centre, University of Cape Town \& GNESD.

De Gouvello, C. \& Kumar, G. 2007. Output-Based Aid in Senegal - Designing Technology-Neutral Concessions for Rural Electrification. Washington, D.C.: GPOBA.

DECRS 2009. Rapport Annuel Conjoint 2008. Coopération entre la République du Sénégal et la Communauté Européenne.: Delegation of the European Commission to the Republic of Senegal.

Diatta, S. D. 2012. Des preuves techniques de malversations sur le bureau du Juge : Ces documents explosifs qui vont couler Aliou Niang, ex-Dg de l'Aser. Rewmi Quotidien, 5th September.

Available: http://www.rewmi.com/des-preuves-techniques-de-malversations-sur-le-bureaudu-juge-ces-documents-explosifs-qui-vont-couler-aliou-niang-ex-dg a67104.html]

Dioh, T. 2003. Sénélec cherche repreneur. Jeune Afrique, 2nd April. Available:

http://www.jeuneafrique.com/Article/LIN30033snlecruenerO/actualite-afriqueseneleccherche-repreneur.html]

Diop, M. 2009. Applications et Impact des Énergies Renouvelables dans l'Électrification Rurale au Sénégal. [Presentation]. ASER, 22 April.

Donor 1.9 July 2012.Interview with Rebecca Mawhood.

Donor 3. 18 July 2012. Interview with Rebecca Mawhood

Dufail, X. 2010. Sénégal : pour raccorder 229000 ménages, l'Aser est à la recherche de 134 milliards FCFA (18/1/2010) [Online]. Réseau Internationale d'Accès aux Énergies Durables. Available: http://www.riaed.net/?Senegal-pour-raccorder-229-000 [Accessed 16th September 2012].

Eberhard, A., Foster, V., Briceno-Garmendia, C., Ouedraogo, F., Camos, D. \& Shkaratan, M. 2008. Underpowered: The state of the power sector in Sub-Saharan Africa. Washington, D.C.: World Bank.

ECJRC 2011. Renewable energies in Africa: current knowledge. Luxembourg: European Commission Joint Research Centre.

Enerdata 2011. Global Energy Market Research: Senegal. Grenoble: Enerdata.

ESMAP 2007. Maximisation des Retombées de l'Electricité en Zones Rurales, Application au Cas du Sénégal. Washington D.C.: Energy Sector Management Assistance Program, World Bank.

Estache, A. 2006. PPI partnerships vs. PPI divorces in LDCs. REVIEW OF INDUSTRIAL ORGANIZATION; Rev.Ind.Organ., 29, 3-26.

Fall, A. \& Wamukonya, N. 2003. Power sector reform in Senegal. In: Wamukonya, N. (ed.) Electricity reform: social and environmental challenges. Roskilde, Denmark: UNEP.

Faye, D. 2012. Portefeuille de la Banque Mondiale au Sénégal : Traque aux faiblesses. Le Quotidien, 3rd July. Available: http://www.lequotidien.sn/index.php/economie/item/12148portefeuille-de-la-banque-mondiale-au-s\%C3\%A9n\%C3\%A9gal--traque-aux-faiblesses] 
Fofana, B. 2011. CUMUL DES DUREES DE COUPURES DE LA SENELEC : 2950 heures de délestage ou 4 mois sur 12. SeneWeb News, 15th January. Available:

http://www.seneweb.com/news/Economie/cumul-des-durees-de-coupures-de-la-senelec2950-heures-de-delestage-ou-4-mois-sur-12 n 39944.html]

Foster, V. \& Briceño-Garmendia, C. (eds.) 2010. Africa's Infrastructure - A Time for Transformation, Washington, D.C.: Agence Française de Développement and World Bank.

Fritsch, R. 2011. Comparative financial analysis of electricity utilities in West Africa. Sustainability of biofuels, 39, 6055-6064.

Gaye, M. 2010. Mission et Objectifs de l'ASER pour une Électrification Globale du Sénégal. [Presentation]. ASER. 23 March 2010.

Gelb, A., Ramachandran, V., Shah, M. K. \& Turner, G. 2007. What matters to African firms? The relevance of perceptions. Washington, D.C.: World Bank.

Gihr, K. 2009. Rural Electrification in SSA - What Works and What Doesn't. Some Considerations. [Presentation]. KfW Entwicklungsbank, 17 June.

GNESD 2004. Energy Access theme results: Summary for Policy Makers (SPM). Roskilde, Denmark: GNESD, UNEP.

Gökgür, N. \& Jones, L. 2006. Privatization of Senegal Electricity. Assessing the Impact of Privatization in Africa. Boston: Boston Institute for Developing Economies.

GoS 1998. Loi n 98-29 du 14 avril 1998 relative au secteur de l'électricité. Dakar, Senegal: Government of Senegal.

GoS 1999. Décret n 99-1254 du 30 décembre 1999 portant création et fixant les règles d'organisation et de fonctionnement de l'Agence Sénégalaise d'Électrification Rurale. Senegal: Government of Senegal.

GoS 2006a. Arrêté Interministériel n 8442 MEM-MEF en date du 18 décembre 2006 fixant le niveau de la redevance d'électrification rurale et ses modalités de recouvrement. Senegal: Government of Senegal.

GoS 2006b. Document de Stratégie pour la croissance et la Réduction de la Pauvreté 2006-2010 (DSRP II). Senegal: Government of Senegal.

GoS 2011. Document de politique économique et sociale : DPES 2011-2015. Placer le Sénégal sur la rampe de l'émergence. Senegal: Government of Senegal.

GoS. 2013. Conseil des Ministres du 4 juillet 2013 [Online]. Senegal: Government of Senegal.

Available: http://www.gouv.sn/Conseil-des-Ministres-du-04,1444.html [Accessed 6th December 2013].

Government 1. 26 June 2012.Interview with Rebecca Mawhood.

Government 3. 4 July 2012.Interview with Rebecca Mawhood.

Government 4. 17 July 2012.Interview with Rebecca Mawhood.

Government 5. 19 July 2012.Interview with Rebecca Mawhood.

Government 6. 23 July 2012.Interview with Rebecca Mawhood.

Government 7. 1 August 2012.Interview with Rebecca Mawhood.

Government 8. 2 August 2012.Interview, with Rebecca Mawhood.

Government 10. 23rd July and 8th August 2012.Interviews with Rebecca Mawhood

Guèye, M. 2012. Aliou Niang, Dg de l'Agence nationale pour l'électrification rurale (Aser) : «L'Aser est hyper-endettée». 7th August. Available:

http://www.lequotidien.sn/index.php/economie/item/13104] 
Gueye, R. D. 2009. Présentation du Fonds d'Électrification Rurale (FER). [Presentation]. Club-ER Groupe Thématique, ASER, Dakar, 15-20 June.

Gupta, S., Tirpak, D. A., Burger, N., Gupta, J., Höhne, N., Boncheva, A. I., Kanoan, G. M., Kolstad, C., Kruger, J. A., Michaelowa, A., Murase, S., Pershing, J., Saijo, T. \& Sari, A. 2007. Policies, Instruments and Co-operative Arrangements. Climate Change 2007: Mitigation. Contribution of Working Group III to the Fourth Assessment Report of the Intergovernmental Panel on Climate Change. Cambridge, U.K. and New York, N.Y.: Cambridge University Press.

Haanyika, C. M. 2006. Rural electrification policy and institutional linkages. Energy Policy, 34, 29772993.

Hoang-Gia, L. 1998. Réunion Sectorielle Énergie - Volet Électrification Rurale -Rapport Préliminaire. Senegal: Cellule de Préparation et de suivi des Réformes du Secteur de l'Électricité, Direction de l'Énergie, Ministère de l'Énergie, des Mines et de l'Industrie, Government of Senegal.

IEA 2011. World Energy Outlook 2011, Paris, IEA.

IEA 2012. WEO-2012 Electricity access database. OECD/IEA.

IEA 2013. WEO-2013 Electricity access database. OECD/IEA.

Ilskog, E. \& Kjellström, B. 2008. And then they lived sustainably ever after?-Assessment of rural electrification cases by means of indicators. Energy Policy, 36, 2674-2684.

IMF 2011. Regional Economic Outlook. Sub-Saharan Africa. Sustaining the Expansion. Washington D.C.: International Monetary Fund.

IMF 2012. Regional Economic Outlook. Sub-Saharan Africa. Sustaing Growth amid Global Uncertainty. Washington D.C.: IMF.

IRENA 2012. Renewables Readiness Assessment: Senegal - Preliminary Findings. Abu Dhabi: International Renewable Energy Agency.

Joe, M. 2013. DETOURNEMENT A L'ASER L'ex-Dg Modibo Diope et ses 4 complices, condamnés à 05 ans ferme. panafricain.com, 18th September. Available:

http://www.panafricain.com/index.asp?page=detail article\&art=82857\&lang=fr\&pi=10]

Jupp, V. (ed.) 2006. The SAGE Dictionary of Social Research Methods, London: SAGE Publications Ltd.

Karekezi, S. \& Kimani, J. 2002. Status of power sector reform in Africa: impact on the poor. Energy Policy, 30, 923-945.

KfW. 2010. Énergies renouvelables et efficacité énergétique [Online]. KfW Entwicklungsbank.

Available: http://www.kfw-

entwicklungsbank.de/ebank/EN Home/About Us/Local Presence/SubSahara62/Office Senegal/Activities/Project4.jsp [Accessed 3rd October 2012].

Kouassi, H. \& Pineau, P. O. 2011. Financing Challenges for Electricity Projects in Sub-Saharan Africa: Reviewing Old Models and Exploring New Ones. Journal of African Business, 2011, 347--367.

Lehtinen, T. O. A., Mäntylä, M. V. \& Vanhanen, J. 2011. Development and evaluation of a lightweight root cause analysis method (ARCA method) - Field studies at four software companies. Special Section on Mutation Testing, 53, 1045-1061.

Massé, R. 2010. Financing Rural Electrification Programs in Africa. Francheville, France: CLUB-ER. Mawhood, R. 2012. The Senegalese Rural Electrification Action Plan: A 'good practice' model for increasing private sector participation in Sub-Saharan rural electrification? Master of Science in Environmental Technology, Imperial College London.

Mostert, W. 2008. Review of Experiences with Rural Electrification Agencies - Lessons for Africa. Draft August 24, 2008. Eschborn, Germany: EUEI-PDF. 
Nanka-Bruce, O. 2010. The socio economic drivers of rural electrification in Sub-Saharan Africa Guildford: Surrey Energy Economics Centre, University of Surrey.

Ndiaye, A. S. 2011. La part des énergies renouvelables dans le projet ERSEN [Slides from presentation: 18/11/2011]. Dakar, Senegal: PERACOD.

Ndoye, M. N. 2013. AFFAIRE ASER: CONDAMNE A 5 ANS DE PRISON FERME - Modibo Diop devra encore purger 27 mois. Groupe Futurs Médias, 18th September. Available: http://www.gfm.sn/actu-lobs/itemlist/tag/AFFAIRE\%20ASER.html]

Niang, A. 2006. Rural Electrification in Senegal. [Presentation]. UNEP/e7 Rural Electrification Workshop, Nairobi, March 1-3.

Niang, A. 2011. Programme d'électrification rurale du Sénégal : opportunités et défis. [Presentation]. Africa Electrification Initiative, Dakar, 16 November.

Nicholls, J., Mawhood, R., Gross, R. \& Castillo Castillo, A. 2014. Evaluating Renewable Energy Policy: A Review of Criteria and Indicators for Assessment. Abu Dhabi, UAE: IRENA.

Onyeji, I., Bazilian, M. \& Nussbaumer, P. 2012. Contextualizing electricity access in sub-Saharan Africa. Energy for Sustainable Development, 16, 520-527.

Prasad, G. 2008. Energy sector reform, energy transitions and the poor in Africa. Energy Policy, 36, 2806-2811.

Rosenzweig, M. B., Voll, S. P. \& Pabon-Agudelo, C. 2004. Power Sector Reform: Experiences from the Road. The Electricity Journal, 17, 16-28.

Sanoh, A., Parshall, L., Sarr, O. F., Kum, S. \& Modi, V. 2012. Local and national electricity planning in Senegal: Scenarios and policies. Energy for Sustainable Development, 16, 13-25.

Sarr, O. 7th March 2014 Personal communication-a. RE: RE: Article sur le PASER.Email to Mawhood, R.

Sarr, O. 4th July 2012 Personal communication-b. RE: RE: Concessions - contacts. Email to Mawhood, $\mathrm{R}$.

Sarr, O. F. 30th May 2012 Personal communication-c. RE: Re: Senegal rural electrification Christophe de Gouvello. Email to Mawhood, R.

SeneNews. 2010. Modibo en prison pour détournement, le préjudice chiffré à plus de 5 milliards. SeneNews, 22nd December. Available: http://www.senenews.com/2010/12/22/modibo-enprison-pour-detournement-le-prejudice-chiffre-a-plus-de-5-milliards/]

SIE. 2012. Taux d'électrification [Online]. Système d'information énergétique du Sénégal, Government of Senegal. Available: http://www.sie-energie.gouv.sn/spip.php?article37 [Accessed 16th September 2012].

Sokona, Y., Sarr, S. \& Wade, S. 2004. Energy Access theme results: Energy services for the poor in West Africa. Roskilde, Denmark: Global Network on Energy for Sustainable Development (GNESD), UNEP.

Sow, A. 2004. La place des ENR dans le programme de l'ASER. [Presentation]. Atelier ER, ASER, Ouagadougou, June.

Sow, A. 2006. Les agencies d'électrification rurale en Afrique subsaharienne. Quebec, Canada: IEPF.

Sow, A. 2009. Le modèle sénégalais d'électrification rurale : enjeux et modalités de la mise en oeuvre d'un partenariat public-privé. [Presentation]. ASER, September.

Sylla, E. H. 2011. Le développement de la filière hybride à l'échelle nationale et les perspectives futures. [Presentation]. ASER, CLUB-ER workshop, 18-22 July. 
Theesfeld, I., Schleyer, C. \& Aznar, O. 2010. The procedure for institutional compatibility assessment: ex-ante policy assessment from an institutional perspective. Journal of Institutional Economics, 6, 377-399.

Thioune, M. E. A. 2012. Les réalisations de l'alternance de 2000 à 2011 : Cheikh Meissa Ndiaye Maréchal des troupes libérales. SunuGalsene.com, 7th March. Available: http://sunugalsene.com/Les-realisations-de-l-alternance.html]

Turkson, J. \& Wohlgemuth, N. 2000. Power sector reform and distributed generation in sub-Saharan Africa. Energy Policy, 29, 135-145.

UNDP 2012. Africa Human Development Report 2012. New York, USA: United Nations Publications.

Wamukonya, N. (ed.) 2003. Electricity reform: social and environmental challenges, Roskilde, Denmark: UNEP.

World Bank 2004. GEF project document on a proposed grant from the Global Environment Facility Trust Fund in the amount of USD 5 million to the Republic of Senegal for an Electricity Services for Rural Areas project in support of the first phase of the Electricity Services for Rural Areas. Energy Unit, Infrastructure Group, Africa Regional Office, World Bank.

World Bank 2012a. Implementation Status \& Results - Senegal - SN-Elec. Serv. for Rural Areas (FY05) (P085708). World Bank.

World Bank. 2012b. Ranking of economies - Doing Business [Online]. World Bank Group. Available: http://www.doingbusiness.org/rankings [Accessed 1st May 2012].

XE. 2012. XE Currency Converter [Online]. XE. Available: http://www.xe.com/ [Accessed Web Page 2012]. 